CATALAN REVIEW

Catalan Review

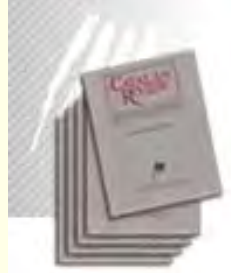

You are accessing the Digital Archive of the Catalan Review Journal.

By accessing and/or using this Digital Archive, you accept and agree to abide by the Terms and Conditions of Use available at http://www.nacs-

catalanstudies.org/catalan_review.html

Catalan Review is the premier international scholarly journal devoted to all aspects of Catalan culture. By Catalan culture is understood all manifestations of intellectual and artistic life produced in the Catalan language or in the geographical areas where Catalan is spoken. Catalan Review has been in publication since 1986 .
NORTH

AMERICAN

CATALAN

SOCIETY
Esteu accedint a l'Arxiu Digital del Catalan Review

A l' accedir i / o utilitzar aquest Arxiu Digital, vostè accepta i es compromet a complir els termes i condicions d'ús disponibles a http://www.nacs-

catalanstudies.org/catalan_review.html

Catalan Review és la primera revista internacional dedicada a tots els aspectes de la cultura catalana. Per la cultura catalana s'entén totes les manifestacions de la vida intel lectual i artística produïda en llengua catalana o en les zones geogràfiques on es parla català. Catalan Review es publica des de 1986.

\title{
Women on the Walls: Women and Warfare in the Catalan Grand Chronicles Linda A. McMillin
}

Catalan Review, Vol. III, number 1 (1989), p. 123-136 


\title{
WOMEN ON THE WALLS: WOMEN AND WARFARE IN THE CATALAN GRAND CHRONICLES
}

\author{
LINDA A. McMILLIN
}

In the popular imagination the Middle Ages are a time of castles, knights, and glorius battles. No medieval literature gives more credence to this image than the Catalan Grand Chronicles. ${ }^{\mathrm{I}}$ These four works cover the time period of 1208 to 1350 , and record the expansion of the kingdom of Aragon-Catalonia into a Mediterranean empire. ${ }^{2}$ In the tradition of the Chansons de geste center stage is given the chivalric deeds of the king and his knigths in battle. ${ }^{3}$ The Llibre dels feyts, the earliest chronicle, is the autobiography of James I ( ruled I213-I276) who succesfully leads the con-

${ }^{1}$ For the best general background on the four chronicles see M. de Riquer, Història de la literatura catalana, vol. I (Barcelona, 1964), 394-501. See also Arthur Terry, A Literary History of Spain: Catalan Literature (London, 1972), 24-30; and J.N. Hillgarth, The Spanish Kingdoms, vol. I (Oxford, 1972), 233-238. The best edition of the chronicles and the one used for this article is Ferran Soldevila, Les qualre gran cròniques (Barcelona, 1971).

${ }^{2}$ On the growth of the Aragonese-Catalan Empire see Jesús Lalinde Abadaía, La Corona de Aragón en el Mediterraneo Medieval, I229-I479 (Zaragoza, 1979); Lluis Nicolau d'Olwer, L'expansió de Catalunya en la Mediterrània oriental (Barcelona, 1926); Ferran Soldevila, Història de Catalunya, end ed. (Barcelona, 1963); and J. Lee Shneidman, The Rise of the Aragonese-Catalan Empire 1200-I350, 2 vols. (New York, 1970). Shneidman should be used with extreme caution; see the review by J.N. Hillgarth in Speculum 47 (1972), 345-53. Hillgarth questions the use of the term empire in his monograph The Problem of a Catalan Mediterranean Empire I229-1327 which was published as English Historical Review, Supplement 8 (London, 1975). Hillgarth's view is disputed by Anthony Luttrell, "Late-Medieval Mediterranean Empires: The Catalan Example" Contributions Mediterranean Studies, ed. Mario Vassalló (Malta, 1977); and Charles-Emmanuel «Un impérialisme médiéval au Maghrid: La naissance et l'essor de l'empire catalan, d'après des traveux récents", Les Cabiers de Tunisie, XX, nos. 79-80 (1972), I0I-124.

${ }^{3}$ Hillgarth, Spanish Kingdoms I, 235. See also Alison Goddar Elliott, "The Historian as Artist: Manipulations of History in the Chronicle of Desclot," Viator, I4 (1983), I95-209; and Beatrice J. Concheff, "The Hypothetical Epic-Narrative 
quests of Mallorca, Valencia, and Murcia. ${ }^{4}$ Bernat Desclot in his work, Llibre del rey En Pere, takes up the story of James's son, Peter II (1276-I285).5 Peter's military exploits include the conquest of Sicily and the defense of Catalonia against the French invasion of 1285 . The Cronica of Ramon Muntaner recapitulates the reigns of James and Peter, and proceeds to tell the stories of Peter's sons Alphonso II (I285-I29I) and James II (I29I-1327). ${ }^{6}$ Muntaner includes his own adventures with the Catalan Company in Constantinople, Asia Minor, and Greece, and the conquest of Sardinia by Alphonso III, James II's son. The last chronicle is the autobiography of Peter III which carries the dynasty through a fifth generation. ${ }^{7}$ Although Peter acquires no new lands, he does manage a

Sources for the Catalan Chronicles of Jaume I, Desclot, and Muntaner", Unpublished Ph. D. diss., University of Wisconsin, 1976.

4 For background on the Llibre dels feyts, including discussion of its autobiographical nature, see Riquer, 294-429; R.I. Burns, Moors and Crusaders in Mediterranean Spain (London, 1978), 1-35; and idem, Muslims, Christians, and Jews in the Crusader Kingdom of Valencia (Cambridge 1984), 285-288, 329. English translation (to be used with caution) by John Forster, The Chronicles of James I, King of Aragorl, 2 vols. (London, 1883). English translations for this article are my own. Throughout this paper the kings will be designated by their regal number for the kingdom of Aragon.

5 For background see Riquer, 429-448. See also José M. Coll, «Algunas referencias inéditas sobre los cronistas Desclot, Muntaner, y Descoll,"Analecta Sacra Tarraconensia, 23 (1950), 67-74. English translation by F.L. Critchlow, Chronicle of the Reign of King Pedro III of Aragon, 2 vols. (Princeton, 1928-34).

${ }^{6}$ For background see Riquer, 449-480. See also Roger Sablonier, Krieg und Kriegertum in der Crònica des Ramon Muntaner (Bern and Frankfurt, 1971); idem, "The Aragonese Royal Family around 1300", in Interest and Emotion: Essays on the Study of Family and Kinship, ed. H. Medick and D.W. Sabean (Cambridge, 1984), 210-239, Nicolae Jorga, "Ramon Muntaner el l'empire byzantin", Revue bistorique de sud-est européen, IV (1927), 3225-355; and R.G. Keightley, "Muntaner and the Catalan Grand Company", Revista Canadiense de Estudios Hispánicos, IV (1979), 37-58. English translation by Lady Goodenough, The Chronicle of Muntaner, Hakluyt Society nos. 47 and 50, 2 vols. (London, 1920-21).

7 For background see Riquer, $48 \mathrm{I}$-50r. English translation with excellent introduction by Mary and J.N. Hillgarth, Pere III of Catalonia: Chronicles, 2 vols. (Toronto I980). 
war with the Genoese. In addition to each king's major military undertakings, the chronicles record a myriad of smaller battles: interdynastic feuds and revolts, border skirmishes with Castile and Islamic Granada, sea battles with pirates, raids on North Africa. Yet this masculine world of kings and knights in battle is not without female characters. The lives of queens and noblewomen are recorded, though only when their deeds have some impact on the waging of war. It is the purpose of this study to gather up these scattered glimpses and to see what roles were undertaken by women in medieval warfare. ${ }^{8}$

Throughout all four chronicles women are most often mentioned in marriage agreements. These agreements usually accompanied all peace treaties and alliances.? Weddings, especially

${ }^{8}$ There has been very little work done on women and war in the Middle Ages. Of the three best works on medieval warfare: C.W.C. Oman, The Art of War in the Middle Ages (Ithaca, 1953); R.C. Smail,Crusading Warfare (Cambridge, 1956); and Phillippe Contamine, War in the Middle Ages, trans. Michael Jones (Oxford, 1984) only Contamine mentions women's involvement. He accords women one paragraph on pages $24 \mathrm{I}-2$. There are scattered references to the possibility of women being involved in warfare throughout the literature on women in the Middle Ages, though the only work to develop the theme at any length for Spain is Estelle Irizarry 's "Echoes of the Amazon Myth in Medieval Spanish Literature" in Women in Hispanic Literature, ed. Beth Miller (Berkeley and Los Angeles, 1980). $53-66$.

9 James I, Llibre dels feyts, III: Peter II and Marie of Montpellier - alliance; idem XVIII: James I and Leonor of Castile - alliance; idem, CCCXLII: Yolanda of Aragon and Alfonso X of Castile-alliance; Ramon Muntaner, Crònica, XI: Pedro III and Constanza of Sicily - alliance; idem, CLXII: Alfonso II and Daughter of King of England - peace agreement (betrothed only, Alfonso dies before marriage can take place); idem, CLXXXII: James II and Blanca of Naples - peace agreement; idem, CXCVIII: Frederick of Sicily and Eleanor of Naplesplace agreement; idem CCII: Frey Roger and niece of the Emperor of Constantinople - alliance; idem CCXLV: James, son of James II, and daughter of king of Castile - peace agreement (Betrothed only, James abdicates before marriage takes place); idem, CCLXXXVII: Constanza of Aragon and James II of Mallorca - alliance; Peter IV, Llibre en quès contenen tots los grans fets..., chap. II, paragraph 3I: Peter IV and Maria of Navarre - alliance; idem, IV, 34: Peter IV and Leonor of Portugal - alliance; idem, IV, 64: Peter IV and Eleanor of Sicily - alliance. 
royal ones, were arranged not for love but for political expediency. The War of the Sicilian Vespers lasts through the reigns of three kings of Aragon-Catalonia, but at the conclusion James II marries Blanca of Naples, uniting in one day two families who have been battling for twenty years. ${ }^{10}$ The chronicler assures us that James and Blanca fall instantaneously in love. Not all such unions, however, are as happy. Peter IV's sister is married to the king of Mallorca. When hostilities break out between the two kings, not only does she opt to return to her brother's kingdom, she reveals her husband's plans for an assassination attempt on Peter. ${ }^{\text {II }}$ Sometimes an arranged marriage, while satisfying a treaty, never takes place. To settle a border dispute a Castilian infanta is betrothed at the age of five to the eldest son of James in and sent to Catalonia to be raised. The son later abdicates to become a monk, leaving the throne to already married Alphonso III. We are never told what happens to the nameless infanta. ${ }^{12}$.

A woman's attractiveness as a marriage partner also stemmed from her personal landholdings. In the absence of a male heir, a woman could inherit land or even a kingdom. Hence James I's holdings in southern France were inherited from his mother, Marie of Montpellier. When tracing his family tree, Peter III is careful to list lands acquired through his mother and grandmother. ${ }^{13}$ At times the woman may not be in possession of her lands; nevertheless, it is her claim that is important. Peter III can justify the conquest of Sicily on behalf of his wife, Constanza, even though her father lost the island and his life in battle with the Duke of Anjou. ${ }^{14} \mathrm{~A}$ similar case involves Isabel of Morea. At her father's death she is ousted from her land by the local nobility. Her mo-

10 Muntaner, CLXXXII.

II Peter IV, III, I9.

I2 Muntaner, CCXLV. E.L. Miron, The Queens of Aragon, (New York, 1913), 169 , indentifies her as Leonor of Castile later to become the second wife of Alfonso IV.

${ }^{13}$ James I, II; and Peter IV, I, 4.

${ }^{14}$ Muntaner, XXXVI. 
ther astutely marries her to a cousin of James II, who raises a fleet to restore her rule. II Unfortunately, prior to returning home, she dies in childbirth. But she produces a son, which settles the issue of inheritance for another generation.

In addition to the passive role of marriage gift, women had a more active hand in the political intrigue which constantly rages before, after, and during armed conflicts. Queens especially are enlisted as advocates on behalf of their male relatives. Most often the appeal is made to another male relative. As the marriage link between two proud male egos, these women are a conduit through which favors can be asked and granted. When Alfonso X needs help quelling revolts in Castile, he sends his wife to her father James I. Her appeal is made not to political expediency, but to paternal love and duty. Despite other conflicts with Alfonso, James responds because "I cannot desert my daughter and my grandchildren". ${ }^{16}$ Soon after his marriage to Constanza, Peter II knights and give offices to several of her relatives and friends. While no direct mention is made of her advocacy, we may assume that Peter was not unaware of the points he earned on the domestic front through such actions. ${ }^{17}$

Women are presented as most tenacious when working on behalf of their sons. While marriage was ideally a lifetime commitment, the kings of Aragon-Catalonia seem to practice serial monogamy. Queens lost by death or discarded through annulment are immediately replaced in the perennial search for a male heir and/or another political alliance. Against this shifting landdscape, with the tendency toward, but no absolute custom of primogeniture, a son could be declared illegitimate or slighter in favor of younger half-siblings. Soon after the birth of James I, his mother Marie of Montpellier leaves her infant con to journey to Rome. There sine spends five years in litigation at the papal court

is Ibid., CCLXIII, CCLXVI.

${ }^{16}$ James I, CCCLXXXII: "no puiz fallir a ma filla ni a mos néts".

${ }_{17}$ Muntaner, S XVIII. 
to insure the validity of her marriage and James's legitimacy. Her efforts are successful, though she dies before she can be reunited with her son. ${ }^{\mathrm{I}}$ Several generations later, the mother of Peter IV is adament in her insistence that Peter be declared crown prince at an early age. Her success does not deter Peter's stepmother in her equally tenacious efforts to carve large chunks from Peter's domain to be inherited by her sons. While the latter is ultimately unsuccessful, she proves the bain of Peter's early reign, stirring up trouble for him among the native nobility and in nearby Castile. ${ }^{19}$

Perhaps the most interesting cases of feminine mediation involve women as peace negotiators. Once again, marriage connections play a large role in thesse efforts. When James I and Alfonso $\mathrm{X}$ of Castile both lay claim to the city of Játiva, it is Jame's wife Violante who ultimacely settles the dispute. The chronicler gives her the astereotypically feminine tools of tears and the ability to play on guilt, and she effectively moves both husband and sonin-law to compromise. ${ }^{20}$ Two other queens successfully negotiate one of the many truces of the War of the Sicilian Vespers. The Queem mother of Naples and her daughter-in-law send a letter to Frederick of Sicily (James II's brother) on behalf of King Robert of Naples asking for one year of peace. The appeal is based on their family ties which the chronicler has Frederick outline: «the Queen (is) my mother-in-law and mother of king Robert, and mother-in-law our brother of Aragon, and so likewise the Queen (is) wife of king Robert and our cousin, ... king Robert is our brother-in-law and his son is our nephew... ${ }^{21}$ This exhaustive account of every possible familial connection goes on for two pages

${ }^{18}$ Bernat Desclot, Llibre del rei En Pere d'Aragó e seus antecessors, LXXVI.

I9 Peter IV, I, 42, 44 .

${ }^{20}$ James I, CCCXLVIII.

${ }^{21}$ Muntaner, CCLX: «és madona la reina ma sogra, mare del rei Robert e sogra de nostre frare lo rei d'Aragon, e així mateiz la reina muller del rei Robert, germana nostra, ... rei Robert és nostre cunyat e son fill és nostre nebotn. 
and is more than enough to motivate Robert and Frederick to halt their hostilities, but only for twelve months.

When it comes to actual battle, all four chronicles ideally accord women, along with children and the elderly, the status of non-combatant. If part of a conquered populace, they might be sold into slavery or even, on occasion, slaughtered; the latter only when a city is taken by storm or is guilty of some communal crime. ${ }^{22}$ But for the most part, harming women, especally Christian ones, is beneath the honor of a true knight and a particularly heinous crime. Thus, both Muntaner and Desclot portray the invading French army as wicked and ignoble by including stories of atrocities committed against women: the rape of a group of nuns at a convent near Perpignan, the rape and murder of a woman in front of the altar of the Blessed Virgin at Peralada, the incineration of a group of women and children responding to a false offer of alms from a French admiral. ${ }^{23}$ Such behavior stands in contrast with that of Peter III. He releases the Queen of Mallorca despite the fact that she has helped her husband, a conspirator with the French, escape from Peter's custody. That she is pregnant at the time is to her advantage. Peter also releases her daughter, though continues to hold two sons. ${ }^{24}$

Despite this non-combatant ideal, the chronicles are replete with exceptional women who are more actively involved in warfare. Queens, while not participants in actual combat, often accompany their husbands to the front lines. For James I, Violante's presence in the newly conquered Valencian territory is part of his overall strategy. It proves to his own men and the enemy

${ }^{22}$ Ibid., CCXXII. The Catalan army slaughters all the inhabitants of Rodesto, including women and children. Muntaner acknowledges the cruelty of this deed but feels it is justified revenge for the murder and quartering of twenty-seven Catalan messengers sent to the city some time before.

${ }^{23}$ Desclot, CXXXVIII: nuns; Muntaner, CXXV: woman at Peralada; ibid., CXXVII: admiral.

${ }^{24}$ Desclot, CXXXV. 
"what a will I have to stay here and conquer this kingdom.»" It also allows him to return to Aragon to gather more supplies, confident that his knights will not desert the Queen at such a lonely outpost. With each successful battle Violante is advanced like an icon to the newly acquired town, showing James's continual resolve. But while first called in as a symbol, Violante takes on the role of one of James's chief advisors. She and an interpreter are the only ones present at several of James's secret negotiations for Valencia City and Játiva. ${ }^{26}$ In later years, James seeks her counsel during the Valencian revolts. ${ }^{27}$ While her lines in the chronicle are reduced for the most part to confirmations of her husband's wisdom, it seems safe to infer that she offers some worthwhile advice if so often consulted.

The chronicles present two additional "advancing icons": Marie of Entenza who accompanies her husband, Alphonso III, on the conquest of Sardinia, and Constanza who is sent to the newly conquered Sicily by Peter II. The chronicles contradict each other, however, as to whether or not either woman acted more than symbolically. Muntaner clearly gives Marie a key role in Sardinia, where she nurses a gravely ill Alfonso back to health. "Assuredly he would have been in great danger of dying if it had not been for the great care of my Lady the Princess; to God and her all must be grateful for his life». ${ }^{28}$ In the Crònica of Peter III, however, no mention is made of Marie's healing powers. Rather, she too falls ill and must be sent to a safe castle further away from the battle front. ${ }^{29}$

A greater conflict exists between the two accounts of Cons-

25 James I, CCXXXVII: "que major volentat hinc havem d'aturar e de conquerre aquest regnen.

${ }^{26}$ Ibid., CCLXXVII-VIII, CCCLIII.

27 Ibid., CCLXI-XIII.

${ }^{28}$ Muntaner, CCLXXIV: «que segurament ell fóra estat a gran condició de morir, si no fos lo gran pensament que mandona la infanta ne féu; per què a Déu e a ella devem tuit grair la sua vida".

29 Peter IV, I, 22, 32. 
tanza's adventures in Sicily. In the account by Desclot, Constanza takes up the office of reigning monarch with a firm hand. When the island is threatened, Constanza plans for its defense. The admiral of the navy reports directly to her. She organizes a successful expedition to rescue her sister from the King of Naples. She judges and imprisons an enemy prince..$^{30}$ While not directly participating in armed conflicts, Constanza is chief strategist and commander. In Muntaner, however, all of these roles are given to Constanza's son, James II. It is he who plans the attack, commands the fleet, and judges captives while the queen sits, approving but silent, by his side. Muntaner does acknowledge that Constanza is the "natural sovereign" of Sicily. However, "the queen is not given to be every day and at all hours in council». Rather, it is "Prince James who whill undertake affairs and the wars" ${ }^{31}$ Instead of an active monarch involved in military matters, Constanza is portrayed as a ceremonial figurehead, most remembered for her piety and generous almsgiving. ${ }^{32}$ It is difficult to give one account more credence than the other, though it is worthwhile to note that James II is only sixteen when sent to Sicily with his mother. In addition, Muntaner habitually relates the prophetically brave deeds of future kings in their youth. ${ }^{33}$

Not all women close to the front lines of battle are of royal blood. Noblewomen, the wives and daughters of knights, are often called to active duty. During the French invasion of 1285 , Dona Alicsèn de Montesquiu is credited with saving her town on the plains of Roussillon. She "did not allow the French to enter

$3^{\circ}$ Desclot, CX, CXIX-CXX, CXXVIII-CXXIX.

${ }^{31}$ Muntaner XCIX: «dona natural d'ells", "la reina no era dat d'estar tots dies e totes hores in consell", "l'infant En Jacme qui adés de present entra en los afers e en les guerres."

32 Ibid., CLXXXV.

33 Hillgarth, Spanish Kingdoms, I, 259. Muntaner also gives a larger role to Peter III in the conquest of Valencia and in the putting down of the Valencian revolts than acknowledged by James I in Llibre dels feyts. 
there but resisted them with much courage».34 No details are given as to her specific actions in battle, though she is clearly in command; the town is said to "belong" to her. Her military acumen is no doubt sharp as she defends her town from four full French assaults and inflicts heavy casualties.

The account of Malcalda Scaletta's role in the defense of Messina during the War of the Sicilian Vespers is a little more expansive. The wife of a captain in Peter III's army, Malcalda is described as being:

...of high spirits and strong in courage and body; she was in truth as valiant as any knight and went about daily with thirty armed horsemen and kept guard over the city and stationed her soldiers wherever they were needed to do battle, whether on the walls or in any other place in the city. ${ }^{35}$

Malcalda's case is striking for a number of reasons. She takes on an active role not in the absence of a man to defend her, but in the presence and with the apparent approval of her husband. As commander of thirty horsemen she must be well versed in military strategy and the use of arms. Her leadership is not exercised at a distance; rather, she rides with her knigths and seemingly at their side. It is no wonder when Peter III visits Messina that Malcalda participates in every council between king and captain. She is always at the king's side "when he walked forth or rode through the city or was hunting. ${ }^{3^{6}}$ That Malcalda has won the respect of

34 Desclot, CXL: "no hi lleixà entrar los francesos, ans se defès a ells fortment".

35 Ibid., XCVI: «molts prous e valent de cor e de cos ... quan era lloc ne temps valia un cavaller, e anava a tots jorns ab trenta cavallers armats, e guaità la ciutat, e capdellava lla on era mester les gents d'armes qui es combatien als murs ne als altres llocs de la ciutat”. Michele Amari, La Guerra del Vespro Siciliano (Palermo, I886), 312-3I4, following a contemporary Italian chronicle, howevwe, sees Macalda as a less than admirable character.

${ }^{36}$ Desclot, XCVI: "on qui anàs ne cavalcàs per vila, ne al la caça». 
her male peers is perhaps best illustrated by the fact that Desclot deems her story worthy of inclusion in his chronicle in the first place.

While one might assume that Macalda Scaletta donned armor when riding about with her horsemen, it is certain that Mercadera, a woman who kept a shop in Perelada, did precisely this during the French invasion of 1285 . With her town besieged by the French army, this woman puts on a man's gown, takes a lance, girds on a sword, carries a shield, and sallies forth to pick cabbages in the bort just outside the city walls. When she comes upon a French knight hopelessly lost in the bort's maze of irrigation ditches, quickly attacks. She wounds the man in the leg with her lance, subdues his horse by a blow to the head with her sword, grabs the reins, and cries, "Knight, you are a dead man if you do not surrender!, 37 Wisely, the Frenchman complies. The woman is rewarded for her valor with the French knight's armor and 200 gold florins in ramson money that he raises. In addition, she is given an audience with the king and is asked to "relate many times how she had captured" the knight. ${ }^{8}$

The chronicler Muntaner clearly sees this woman's actions as extraordinary, "a marvelous thing». His purpose in including her story is to ridicule the invaders and to show that «the anger of God" was upon the French. ${ }^{39}$ Yet this should not discount the story's veracity. Muntaner was a native of Peralada, was present during the French siege, and testifies to knowing the woman personally. $4^{\circ}$ Once again a woman is presented who acts independently, without any intervention from a husband or male relative. She ventures outside the walls alone. She does not flee from but initiates the confrontation with the knight. She alone reaps the benefits of her actions. While it is clear women did not often

37 Muntaner, CXXIV: "Cavaller: mort sóts, si no us retets".

$3^{8}$ Ibid.: "contar moltes vegades con li era pres'"

39 Ibid.: "una meravella," "la ira de Déu».

40 Riquer, $449-50$. 
singlehandedly capture enemy soldiers, questions remain as to whether all of this woman's actions were so uncommon. How often did women go outside the walls of a besieged city to gather food? Did they do so alone or in groups? Guarded or unguarded? Armed or unarmed? Muntaner's tone suggests that the food-gathering expedition itself was not so odd; he does not comment on the novelty of the other circumstances.

The bravery of this love woman of Peralada is matched and perhaps exceeded by a whole "army" of women who defend the Catalan camp at Gallipoli. This incident is recorded by Muntaner and is again taken from his personal experience. While the greater portion of the army is away on a raid, Muntaner is left in command of seven knights, r3s footsoldiers, 2000 women, and an unrecorded number of children. ${ }^{4 \mathrm{I}}$ In this vunerable state, they are attacked by the Genoese fleet. Because he lacks sufficient numbers to "man" the defense, Muntaner is forced to utilize women. "I made all the women who were there put on armour and ordered them to the walls". These irregular recruits fight well enough to earn a few lines of praise:

The battle was very hard, and our women defended (the walls) with stones and pieces of rock in so masterly a manner it was marvelous; indeed, a woman was found there who had five wounds from flying stones on her face, who still continued the defense as if she was not hurt. ${ }^{42}$

While credit for the victory and the lion's share of the narrative is given over to the brade deeds of the male soldiers, it is clear that the battle would have been lost it not for the women on the walls. Muntaner sees his use of women for defense as unusual, but he

\section{$4^{\mathrm{t}}$ Muntaner, CCXXVI.}

42 Ibid., CCXXVIII: "jo fiu guarnir totes quantes fembres hi havia e ordonéles als murs", "La batalla fo molt forts, e les nostres fembres, ab cantals e pedres, defensaven tan règeu que meravella era. Que en veritat, que fembra s'hi trobà que havia cinc cairellades en la cara, que encara se defensava aixi con si no hagués mal». 
has run out of options. What is more curious is his nonchalant acceptance of the presence of these "non-combatants» in the camp in the first place. The Catalans were invited to the area to work as mercenaries for the emperor of Constantinople. Their purpose is to fight, pillage, and return home with booty. Yet when the company sets out «the greater part brought along their wives or their mistresses and their children". 43 The list of exceptional women on the battlefield expands, then, from an occasional queen to a few individuals defending their own towns, to a great number of women accompanying their husbands and lovers on an overseas military campaign.

The Catalan Chronicles, while based on historical events and figures, present a narrowly focused, idealized world. The business of men is to wage war. Battles are accorded chapters; peacetime, paragraphs. Knights are brave and true and, if ever cut down, take scores of the enemy to the next life with them. Victory is foreordained. Defeat is either not mentioned or glossed over as a minor setback to be avenged in the next battle. Women are beautiful icons to be protected as non-combatants and traded as marriage gifts. Yet because these chronicles are trying to capture the lives of real men and women, their authors must struggle with those events and individuals who stray from their preordained categories. Defeats, betrayals, mismanagement, and death must be accounted for. So, too, the chroniclers cannot ignore those exceptional women who move from assigned passivity to actively influencing the masculine world of war. The sheer number of these women prompts one to question how far the ideal may be at variance with the reality. This is nothing new; women have been refusing to stay in their assigned roles since the beginning of time. On a human level, it only makes sense that women would not sit passively by while their homes and families are threatened. Desperate times seek desperate solutions.

43 Ibid., CCI: "la major part menaven llurs mullers o llurs amigues, e llurs infants". 
The women in the Catalan Chronicles, however, raise issues that go beyond their individual "desperate times". When called upon, several of these women have skill with arms and knowledge of military strategy. Where was this training acquired and how widespread was it? In a society whose inheritance laws claimed that armor was passed to male heirs only, how did Mercadera of Peralada have access to sword, lance, and shield? ${ }^{44}$ The women at Gallipoli are not camp-following prostitutes; this raises questions about the participation of women in offensive armies. ${ }^{45}$ Going beyond warfare, these catalanes shed new light on the power that women exercised in familial roles: in relationships with husbands, sons, and fathers. More importantly, many are strong women acting alone - worthy to be reclaimed as role-models if not representative of a wider group. These issues go beyond the scope of this article, however, and must be examined in light of other documentary and literary sources. This is but a first step: to bring to light the Catalan Chronicles as an extraordinary and colorful window on thirteenth-century life and to hold up the exceptional women contained in their pages as a challenge to the chroniclers' own chivalric ideal.

LINDA A. MCMILLIN University of California. Los Angeles

44 Heat Dillard, Daughters of the Reconquest (Cambridge, 1984), 29. Dillard bases her assertion on inheritance laws in Castile and does note exceptions.

45 For more on women in offensive armies see James A. Brundage, "Prostitution, Miscegenation, and Sexual Purity in the First Crusade," Crusade and Settle$m e n t$, ed. Peter W. Edbury (Cardiff, 1985), 57-66. For an interesting contemporary account of women on the third Crusade see that of Ad-Din and Ibn Al-Athir in Arab Historians of the Crusades, ed and trans. Francesco Gabrieli, English trans. E.J. Costello (Berkeley and Los Angeles, 1969), 182-189, 204-207. I suspect that many other medieval chronicles expand on this theme. 